\title{
Military Influence on Industrial Policy in Brazil \\ During the 20th and Early 21st Centuries
}

\author{
Vitelio Brustolin
}

\begin{abstract}
The defense industry is part of a country's industrial base and often has multiple uses, serving both civilian and military purposes. It does not stand alone and is a significant part of the country's industry. From this perspective, this article demonstrates the Brazilian military's influence on industrialization policies. Such influence has not always been vested with legitimacy, as in the 1964 coup d'état and the subsequent military government (1964-1985), nor has it always been due to internal reasons. Political-military events, such as World War I and especially World War II, have directly affected the country's industrialization policies. The methodology employed in this article is a review of policies, institutions, laws, and historical facts. The conclusions highlight that during the 20th century Brazil went from the stage of not producing defense equipment to the status of one of the largest exporters in the world. This role underwent profound changes in the 1990s, and 2000s. However, there are threats that a new dictatorship could be established in Brazil. If the country suffers another democratic-era coup d'état, what happened in the 1990s could repeat itself. That is, deindustrialization and the subsequent dismantling of what remains of the defense industry, which would also affect the civilian industry.
\end{abstract}




\section{Introduction}

What is the military's influence on Brazilian industrialization policies? This is the question that motivates this article. It is a broad question, covering centuries of history. However, due to its importance for the industrialization of Brazil, World War I will be used as the starting point for the present discussion. The article therefore covers the period of 1914 until the date this article was submitted for publication in January 2022. Thus, the research question that drives this study spans practically the entire 20th century and the first two decades of the 21st century.

It is important to emphasize that the term 'military influence' refers to both internal and external factors Throughout the article, therefore, import limitations imposed by the First and Second World Wars (i.e., external factors) are understood to have forced Brazil to develop part of its local industry. Internal military influence is also discussed, such as the dictatorial military regime that began in 1964 and lasted until 1985. The concept of 'policy' employed here is thus a broad one. That is, not only will laws and documents published by governments be discussed, but so will "policy as representative of all interests of the community", as defined by Clausewitz (1976 [1832], p. 607). ${ }^{1}$

Through a review of policies, institutions, laws, and historical facts, this article argues that the defense industry is part of a country's industrial base and often has multiple uses, serving both civil and military purposes. In this way, the defense industry does not stand alone and is a significant part of a country's overall industry. The article is divided as follows. Following this introduction, I begin by outlining the main institutions that have comprised Brazil's defense industrial base during the 20th and early 21st centuries. The next sections discuss the concept of 'multiple use innovations' - including some of the technologies produced by Brazil; the main military and civilian higher education institutions in the country; universities, colleges, and technical education centers; defense companies and industries; the Navy's Nuclear Program; the Aerospace Sector; and, finally, the Brazilian Defense Industries Association. Within this final section, academic research on military affairs, defense industry laws, and new threats to Brazil's democracy are also discussed.

\section{Historical background}

The import limitations imposed by World War I gave Brazil its first perspective into the process of import substituted industrialization that would take place following the 1929 Crisis and the Great Depression (Mattei and Santos Júnior, 2009). Although the government played a limited role in stimulating industry in the 1920s, the War increased the perception of the importance of industry in general, and especially in the area of warfare (Vinhosa, 1990).

During the 1920s, Brazil's iron, steel, and cement industries began to receive increasingly

\footnotetext{
${ }^{1}$ Clausewitz, On War (1976) [1832], p. 607 [VIII, 6b: 607]; cf. Clausewitz, Vom Kriege, (1980) [1832], p. 993 [VIII, 6b: 993]: "Daß sie eine falsche Richtung haben, dem Ehrgeiz, dem Privatinteresse, der Eitelkeit der Regierenden vorzugsweise dienen kann, gehört nicht hierher; denn in keinem Fall ist es die Kriegskunst, welche als ihr Präzeptor betrachtet werden kann, und wir können hier die Politik nur als Repräsentanten aller Interessen der ganzen Gesellschaft betrachten." [N.A.: Emphasis added].
} 
frequent incentives from the government. These incentives took the form of tax exemptions, as well as freight benefits on public railroads. Ferreira Lima points out that with US capital Brazil increasingly assembled motor vehicles locally. Such capital also impacted oil refining, the chemical and pharmaceutical industries, and the manufacture of machinery and tires (Ferreira Lima, 1978).

The period that extends from the arrival of the Portuguese royal family in Brazil, in 1808, until the Revolution of 1930, is known among the industrial cycles as the "Implantation". Following the Revolution of 1930, Brazil went through a modernization process (Skidmore, 1999). ${ }^{2}$ According to Amarante, this was the time of the country's First Military Industrial Cycle. Previously, its entire military industrial infrastructure used foreign technologies (Amarante, 2004, p. 25). The period from 1930 to 1956 is called the "Industrial Revolution" cycle.

Getúlio Vargas came to power with the Revolution of 1930 - and remained until 1945. During these 15 years, he invested in the creation of industrial infrastructure. In particular, special attention was given to basic industries and energy, also called production goods industries. Highlights of the period include the creation of the National Petroleum Council (Conselho Nacional do Petróleo, 1938) (FGV, 2021a), the National Steel Company (Companhia Siderúrgica Nacional, 1941) (FGV, 2021b), the Vale do Rio Doce Company (Companhia Vale do Rio Doce, 1943) (FGV, 2021c), and the São Francisco Hydroelectric Company (Companhia Hidrelétrica do São Francisco, 1945) (FGV, 2021d).

Brazil's participation in World War II was on the Allied side, meaning the country had not experienced war conflict for seven decades (Brayner, 1968). ${ }^{3}$ The industries that were installed in the country after World War I focused primarily on the assembly of imported parts. However, at the beginning of World War II, Brazil was no longer able to import the parts and machinery necessary for production, due to the global focus of the war industry at that time. Therefore, the cycle of Brazilian Military Research and Development that took place at this time can be seen as a consequence of the Second World War (Amarante, 2004, p. 26). It was precisely in 1945, the year the Second World War ended, that President Getúlio Vargas resigned, making way for elections. ${ }^{4}$

The second Vargas government (1951-1954) was marked by investment in State entrepreneurship. In 1952, the National Bank for Economic Development (Banco Nacional de Desenvolvimento Econômico), the BNDE, was created (which would later, in 1982, be renamed BNDES, with the addition of "Social") (BNDES, 2021). At this time, a military cooperation agreement with the United States, signed in 1952, dampened Brazilian military technological development. Brazil gained access to low-cost equipment but left local production in the background (FGV, 2021e).

This period also saw the creation of what was then known as the National Campaign for the Improvement of Higher Education Personnel (Campanha Nacional de Aperfeiçoamento de Pessoal de Nível Superior, 1951). Later, in 1961, it would be renamed the Coordination for the Improvement of

\footnotetext{
${ }^{2}$ A coup d'état that overthrew the so-called "Old Republic". This, in turn, had succeeded the Imperial Government after the Proclamation of the Republic in 1889.

${ }^{3}$ Brazil was also the only Latin American country to take part in the First World War. The previous warlike event for the country is the Paraguayan War, which ended in 1870, more than one and a half century ago.
}

${ }^{4}$ Later, in 1950, Getúlio Vargas returned to power elected by popular vote. 
Higher Education Personnel (Coordenação de Aperfeiçoamento de Pessoal de Nível Superior, CAPES) (CAPES, 2021). Additionally, in 1951, the National Research Council was created, which would later, in 1974, be renamed to the National Council for Scientific and Technological Development (Conselho Nacional de Desenvolvimento Científico e Tecnológico, CNPQ) (FGV, 2021f). Both CAPES and CNPQ started to play an important role in the financing of scientific and technological research in the country. The focus was on initiatives, including industrial production and defense. Furthermore, military and civilian higher education institutions also became crucial to the industrialization of the country, which will be discussed later on. Developments during this period included Aeronautics Institute of Technology (Instituto Tecnológico de Aeronáutica, ITA, 1950) (ITA, 2021) and the Military Institute of Engineering (Instituto Militar de Engenharia, IME, 1959), (IME, 2021). In the civilian sphere, the Federal University of Rio de Janeiro (Universidade Federal do Rio de Janeiro, UFRJ, 1920) (UFRJ, 2021a) and the University of São Paulo (Universidade de São Paulo, USP, 1934) (FGV, 2021g) were created, representing many other institutes, universities, colleges and technical education centers.

This framework, developed by the state, helped President Juscelino Kubitschek (1956-1961) launch a Target Plan that accelerated the process of the Brazilian economy's internationalization. The focus was on the energy and transportation sectors (FGV, 2021h). The period - beginning in 1956 and extending to the present day - is known as the "Internationalization" cycle.

In 1964, a military government was installed, lasting almost 21 years, until 1985. By the 1960s, the industrial base had reached a level of development that made production for military applications feasible in the Navy (Amaral, 2013). In the late 1960s and early 1970s, this production also included the Air Force and the Army (Ferreira, 2011).

In 1977, the government of Ernesto Geisel denounced the agreement that had been signed in 1952 between Brazil and the United States, the aim of which was to defend the Western Hemisphere (FGV, 2021i). The termination of the agreement led Brazil to prioritize its own war industry (Brustolin, Oliveira and Peron, 2020, p. 17). The defense industry reached its peak at the end of the 1980's and the country became the eighth largest exporter of military equipment in the world. At the time, it sold equipment to 32 countries, through a company known as Engesa which produced armored vehicles (Amarante, 2004, p. 26). In 1985, another company, Avibras, sold US 1 billion in missile and rocket launchers. Brazil's own Armed Forces (FAs) could therefore place their orders with Brazilian companies (Godeiro, 2010, p. 1).

Until the end of the 1980s, about $90 \%$ of the means that mobilized the Army were manufactured on national territory (Amarante, 2004, p. 27). The military government came to an end in 1985, in a transition toward re-democratization (Couto, 1999). Thus, in Brazil, as in the United States, the President of the Republic, elected by popular vote, resumed the post of "Supreme Commander" of the Armed Forces (Brasil, 1988). ${ }^{5}$ Since then, there have been eight civilian governments: José Sarney (1985-1990), Fernando Collor de Mello (1990-1992), Itamar Franco (19921994), Fernando Henrique Cardoso (1995-2002), Luiz Inácio Lula da Silva (2003-2010), Dilma Vana Rousseff (2011-2016), Michel Temer (2016-2018), and Jair Messias Bolsonaro (2019-2022).

\footnotetext{
${ }^{5}$ In the US, this denomination is Commander in Chief.
} 
The political and social transformations of the 1990s and 2000s brought with them the "near annihilation of the defense industrial base. There was a considerable reduction of activities in national R\&D centers, especially those that constitute the scientific-technological base of defense" (Amarante, 2004, p. 27). It is worth noting that worldwide there was significant disinvestment in the area of defense during the 1990s (Silva \& Marksteiner, 2021, p. 1). This occurred mainly due to the dissolution of the Soviet Union and the end of the Cold War. Such events made the international system unipolar, falling under the leadership of the United States (Brustolin, 2014). However, since defense is a strategic area, Brazil might have avoided the dismantling of its defense industry (Amarante, 2004). With the support of some public policies - which are common for the defense industry worldwide - many defense companies could have sustained themselves by producing multiple-use technologies (Cardoso, 2004, pp. 192-95). Nevertheless, the civilian governments that led Brazil following the military dictatorship (in the late 1980s and 1990s) did not rescue the defense industry. According to Ambrósio, "at the end of the period of military governments, the Armed Forces lost priority in the allocation of resources" (Ambrósio, 2016, p. 22, translated by the author). It is important to note that the share of the entire industry as part of Brazil's Gross Domestic Product (GDP) decreased from 33.7\% in 1980 to 29.1\% in 1993 (Pinheiro, 1996). "This conjunction of factors both political and economic - caused most military programs to suffer successive delays, with many of them being totally or partially canceled" (ABDI, 2011, p. 10, translated by the author).

The Ministry of Defense (MD) was created in 1999. Prior to this, the three Armed Forces were kept in separate ministries. The MD began to concentrate the demands of the Forces for the production and acquisition of defense equipment. Despite this, the pattern of dismantling the industry continued over the following years, also permeating the 2010s (Brustolin, 2014).

A new vision for the role of both the Armed Forces and of science and technology through the military has been expressed through the first published editions of the National Defense Strategy (Estratégia Nacional de Defesa, END): "It is not evident for a country that has had little dealings with wars to convince itself of the need to defend itself in order to build itself" (Brasil, 2008, 2012, p. 1, translated by the author). It is the END itself that seeks to demonstrate the importance of the area:

The arguments that invoke the usefulness of defense technologies and knowledge for the development of the country are not enough, even though they are useful and even indispensable. The resources demanded by defense require a transformation of consciences (Brasil, 2008, 2012, p. 1, translated by the author).

Throughout its history, Brazil has invested- and continues to invest - substantial resources into defense. This is true even with the country's relatively short military tradition compared to other geopolitically close countries. Budgetary analysis of the last 20 years demonstrates that defense in Brazil has remained among the four ministries with the highest federal budget forecast. It is among the three ministries with the highest spending. The country's military expenditures, in current-day US dollars, are higher than those of any other nation in Latin America, and currently put the country in the 15th position worldwide (Silva and Marksteiner, 2021, p. 2). However, the government's use of resources in the area of defense becomes less significant when considered in relation to its Gross Domestic Product. In this case, the Brazilian average over the last 20 years has remained in the margin of $1.5 \%$ of GDP, below that of neighboring countries and members of the BRICS members, 
with the exception of South Africa (Brustolin, 2014). The question of "how resources are distributed" and "how the country's industrial base is fostered", are as important as "how much is allocated to defense".

\section{Multiple use innovations}

Military and civilian technologies are closely tied. Yet when new technologies are developed, it can be hard to discern how exactly they will be applied. In this way, both "will almost always have dual utility, military and civilian", as the National Defense Strategy (END) points out (Brasil, 2008, translated by the author). This versatility in the use of technology is described in academic literature as "multiple use". Below, drawing from Cardoso, is a list technological innovations and military knowledge that have had civilian use in Brazil (Cardoso, 2004, pp. 192-95):

Table 1

\begin{tabular}{|c|c|}
\hline \multicolumn{2}{|r|}{ Military Innovations Developed in Brazil and Presented as Multiple Use } \\
\hline $\begin{array}{l}1969- \\
1971:\end{array}$ & $\begin{array}{l}\text { "Creation and implementation of Embraer. Projects of Ipanema and Xavante, base of the Brazilian } \\
\text { aeronautical industry. }\end{array}$ \\
\hline \multirow[t]{3}{*}{ 1970s: } & $\begin{array}{l}\text { - Self-propelled devices gave rise to missiles, anti-tank rockets and, more recently, the Satellite } \\
\text { Launch Vehicle. }\end{array}$ \\
\hline & $\begin{array}{l}\text { - Armored vehicles on wheels (Urutu and Cascavel) - boomerang suspension also used in off-road } \\
\text { vehicles for civilian use. }\end{array}$ \\
\hline & $\begin{array}{l}\text { - PAL-M TV system - project developed at the Military Institute of Engineering (IME) aiming at } \\
\text { monitoring military operations. }\end{array}$ \\
\hline \multirow[t]{2}{*}{ 1980s: } & $\begin{array}{l}\text { - Navy Nuclear Program - submarine with nuclear propulsion; uranium enrichment by } \\
\text { ultracentrifugation (technology already mastered). }\end{array}$ \\
\hline & - Army Nuclear Program - reactor technology; obtaining high purity graphite. \\
\hline \multirow[t]{2}{*}{ 1990s: } & - Research into carbon fiber technology begins. \\
\hline & - Food irradiation. \\
\hline \multirow[t]{4}{*}{ 2000s: } & - New materials for paving - calcined clay (road construction in the Amazon rainforest). \\
\hline & - Biosafety facilities (defense and health). \\
\hline & $\begin{array}{l}\text { - Processing of voice and image signals (intelligence and public safety service) - development of } \\
\text { filtering systems for transmission and recognition of voice signals. }\end{array}$ \\
\hline & - Communications Systems - tele-detection and electronic countermeasures. (Public Safety, \\
\hline
\end{tabular}




\begin{tabular}{|c|}
\hline telephone cloning, etc.). \\
\hline - Materials for electronic devices - thin films for solar cells and infrared detectors. \\
\hline - Electric generation with hydrokinetics - prototype development. \\
\hline $\begin{array}{l}\text { - Mechanized troop monitoring system. (Defense and public security) - vehicle monitoring } \\
\text { system via radio network in conjunction with the global positioning satellite system (GPS). }\end{array}$ \\
\hline $\begin{array}{l}\text { - Alternative energy sources from national materials - sustainable development. Obtaining } \\
\text { vegetable diesel oil using new niobium-based materials as catalysts. }\end{array}$ \\
\hline - Information security - cryptography. \\
\hline - Digitized cartography. \\
\hline $\begin{array}{l}\text { - Unmanned Aerial Vehicles (UAV) - reconnaissance and search systems, with application in } \\
\text { agriculture, monitoring forest reserves, border areas, etc. }\end{array}$ \\
\hline - Command and control systems (tactical and strategic levels) - also applicable to public security. \\
\hline $\begin{array}{l}\text { - Thermal batteries - for missiles and also for activating rockets on board satellites (orbit } \\
\text { correction). }\end{array}$ \\
\hline - Hybrid vehicle - carbon fiber research from mesophase pitch." \\
\hline
\end{tabular}

Table elaborated with information from: Cardoso (2004, pp. 192-95, translated by the author).

In the same collected volume in which Cardoso presents his data, Alves (2004), referring to Brazil, states: "The absence of continuity of several projects and the complete abandonment of dominated technologies are among the strongest restrictions to scientific-technological and industrial progress. Added to this is the absence of the purchasing power of the state, used by industrialized countries as a lever for development" (Alves, 2004, p. 145, translated by the author).

The author points out that, in the 1970s, Brazil's dual-use materials mainly came from government industries and small and medium-sized companies, some of which started in the country's universities and research centers. Such materials included communications systems, electronics, armored cars, rockets, missiles, and aircrafts. "This process had as a consequence the technological development, the improvement of the industrial production conditions, the generation of employment and economic reflexes, especially in exports" (Alves, 2004, p. 145, translated by the author). By the 2000s, only the activities of the Brazilian Navy in the nuclear area and the Brazilian Space Program stand out as technologies of dual use (subject to international restrictions). Hindering the innovative progress is the fact that " $t]$ hese activities do not contemplate, for the most part, the publication or disclosure of results, processes and methods used in their development" (Alves, 2004, p. 146, translated by the author). Due to the lack of publication and disclosure, such activities do not fit the evaluation criteria of the Brazilian research and education funding agencies. As Alves points out, since these criteria are fundamental to those with scientific and technological careers, non- 
disclosure hinders the participation of researchers from institutions other than those conducting the research (Alves, 2004, p. 146).

\section{Military and civilian institutions of higher learning}

After this brief introduction and summary of Brazil's technological inventory, it is important to highlight Brazil's most prestigious military institutions of higher education in the country. It was these institutions that created the first engineers and researchers who boosted the Brazilian industry in the twentieth century (IME, 2021). Specialized training and academic research have played an important role in the qualification of the professionals who work in related industries, educational institutions, and government. The list presented below is not exhaustive.

\subsection{Army}

Within the Army, the Military Institute of Engineering (IME) stands out. Its history dates back to 1792, with the creation of the Royal Academy of Artillery, Fortification, and Design (Real Academia de Artilharia, Fortificação e Desenho). For decades, the Army was the only Brazilian institution to graduate civil engineers (IME, 2021). During World War II, the Military Institute of Technology was created (Instituto Militar de Tecnologia, 1941) and installed in a building in Praia Vermelha, Rio de Janeiro (1942), marking the beginning of research into equipment for the war industry. In 1959, the Military Engineering School (Escola de Engenharia Militar) was merged with the Military Institute of Technology, becoming the Military Institute of Engineering (Lucena, 2005).

As for academic research, emphasis was placed on the School of Command and General Staff of the Army (Escola de Comando e Estado-Maior do Exército, ECEME), whose history has its roots in the transfer of the Portuguese Court to Brazil (1808-1821), when the Court's Headquarters was established in Rio de Janeiro. ECEME currently offers academic masters and doctorates to military personnel and civilians (ECEME, 2021).

\subsection{Air Force}

The "Ministry of Aeronautics" (Ministério da Aeronáutica) was created in 1941 when Army and Navy aviation bodies were merged (FAB, 2021). In 1943, during an aircraft acquisition trip to the United States, the Army Pilot (who would later become Air Marshal), Casimiro Montenegro Filho, visited the Massachusetts Institute of Technology (MIT). He returned to Brazil with the intention of founding a similar institute, with a focus on aeronautical technology. With the help of professor and head of MIT's Department of Aeronautical Engineering, Richard Harbert Smith, the guidelines for the new institution were created. Decree 27.695/1950 transferred training courses for aeronautical engineers from the Aerospace Technical Center (Centro Técnico Aeroespacial, CTA, today Departamento de Ciência e Tecnologia Aeroespacial DCTA) to the Aeronautics Institute of Technology (ITA). The Institute would end up being a pioneer in post-graduate engineering in Brazil. The ITA graduated the first cohort of Masters in Engineering in the country in 1963, and the first Doctor in 1970. In 1969, 
with the creation of the Bandeirante, a regional aircraft, the company Embraer was founded on the same ITA campus, in the city of São José dos Campos, São Paulo (ITA, 2021).

The University of the Air Force (Universidade da Força Aérea, UNIFA) clearly stands out within academic research. This institution began to take shape in 1912, when a plot of land on the Afonsos Farm (Rio de Janeiro), where the Brazilian Aeroclub (Aeroclube Brasileiro) was located, was chosen to build the Brazilian Aviation School (Escola de Aviação Militar, which was inaugurated in 1914). In 1941, with the creation of the Brazilian Air Force (Força Aérea Brasileira, FAB), it was renamed the Afonsos Air Base (Base Aérea dos Afonsos). UNIFA currently offers a Master's degree to military personnel and civilians, and has been authorized to offer a professional doctorate (FGV, 2021j).

\subsection{Navy}

Of all the Navy's educational institutions, the Naval War College (Escola de Guerra Naval, EGN) is the most well-known. Its history dates back to 1911, with the creation of the Navy Superior Course (Curso Superior de Marinha), (EGN, 2021a). Today the EGN is aimed at training officers for operations and administration, as well as military and civilian personnel, with professional master's and doctoral programs (EGN, 2021b).

In the area of internal research, one of the main references is the Navy Technology Center in São Paulo (Centro Tecnológico da Marinha em São Paulo, CTMSP), created in 1986, and the Navy's Nuclear Program (Programa Nuclear da Marinha) (CTMSP, 2021a). For its antiquity and scope, it is also worth mentioning the Naval School (Escola Naval). Its history begins in 1782, in Portugal, with the creation of the Royal Navy Guards Academy (Academia Real de Guardas-Marinhas) (EN, 2021).

\subsection{Superior War College}

In 1949, Law 785 officially created the Superior War College (Escola Superior de Guerra, ESG) (ESG, 2021). With the creation of the Ministry of Defense in 1999, ESG is now directly subordinated to the Ministry of Defense (Dórea, 2018, p. 57). ESG trains military personnel and civilians, with a focus on leadership and advisory services for national defense planning (ESG, 2021). Recently, ESG also began offering an academic master's degree, whose first cohort was enrolled in 2019 (EGN, 2018).

\section{Universities, colleges, and technical education centers}

There are many universities, colleges, and technical education centers that train professionals who work in Brazil's defense industry. Besides the main military educational institutions listed above, there are traditional civilian educational institutions, among which two stand out. The first is the Federal University of Rio de Janeiro (Universidade Federal do Rio de Janeiro, UFRJ): created in 1920, by Decree 14,343 (Oliveira, 2021). UFRJ has its roots in the Polytechnic School, which originated from the Royal Academy of Artillery, Fortification, and Design, established in 1792 (just like the IME, mentioned earlier), (UFRJ, 2021b). The second it the University of São Paulo (Universidade de São Paulo, USP). Created in 1934 (USP, 2021a), USP has its roots in the University of São Paulo Law School 
(Faculdade de Direito da Universidade de São Paulo, FDUSP), created in 1827 (USP, 2021b) alongside with the Recife Law School (Faculdade de Direito do Recife), (UFPE, 2021).

These institutions represent the activities of thousands of others, which have a substantial role for the entire industry and which would make an article on their own. To get an idea of the current numbers, considering only the stricto sensu graduate courses recognized by CAPES: 3,690 are master's and 2,443 are doctoral (Plataforma Sucupira, 2021). In total, there are 7,054 recognized stricto sensu post-graduation courses in Brazil. In addition to these, there are thousands of lato sensu courses. In addition, the latest available data show that there are 33,000 undergraduate courses in 2,364 higher education institutions. There are also thousands of technical courses, which are formatted in 185 types, divided into 12 technological axes (Educa Brasil, 2021). The educational institutions act not only in the training of industry professionals, but also in the multidisciplinary training of both military and civilian professionals.

\section{Companies and industries}

The trajectory of the main defense companies in the country is directly linked to the role of the State. There are, in this context, some notable cases. The history of the aviation industry in Brazil, for example, is marked by State entrepreneurship. The trajectory of some emblematic companies and industries is presented below. Again, it should be noted that the cases listed are not exhaustive.

\subsection{Imbel}

Brazilian Army Material Industry (Indústria de Material Bélico do Brasil, Imbel) is a state-owned company, created in 1975, by Law 6,227, and is linked to the Army. Imbel is the result of the rearrangement of five existing weapons factories in Brazil. Its history dates back to 1762, at the beginning of the defense industry in the country, when it was still a colony of Portugal (Imbel, 2021a). Currently, Imbel's main products include: rifles, carbines, assault rifles, pistols, knives, ammunition, gunpowder, explosives, temporary shelters, and communication and electronic systems (Imbel, 2021b).

\subsection{Helibras}

Helibras, a company focused on the helicopter industry, was created by the Brazilian government in 1978, within the Aerospace Technical Center (CTA). Its initial partners were the French companies Aerospatiale, and Aerofoto Cruzeiro. The private partnerships, however, were soon shaken off, due to the economic difficulties that the company suffered in the beginning (Laux, 2013). In 2014, due to the restructuring of the Airbus Group, Airbus Helicopters took control of Helibras (Helibras, 2021). To this day, the first helicopter manufactured by Helibras, the AS350 Esquilo, is the world's bestselling turbine-powered model. Between $48 \%$ and $54 \%$ of the parts used in this model is produced domestically (Laux, 2013). 


\subsection{Avibras}

Avibras produces a range of products from aircraft artillery systems and rockets to missiles and armored vehicles. It was founded in 1961 by engineers from ITA. It is one of the first companies in Brazil to work on aircraft construction and to participate in space research programs. In the 1960s, the company began developing rockets for surface-to-surface use and missiles for the Army, as well as air-to-ground rocket systems and helicopter weapons for both the Brazilian Air Force and Navy. As presented in the beginning of the article, the 1980s marked a large volume of exports for Avibras, especially with the artillery rocket systems for area saturation (ASTROS). It is worth noting that Avibras is internationally recognized for its technological solutions (Avibras, 2021).

\subsection{Embraer}

The creation of the "Ministry of Aeronautics" on 20 January 1941, had the explicit function of expanding the "development achieved by national aviation", and took into consideration that efficiency and aeronautical equipment "are decisive for national progress and safety", as described in the Explanatory Memorandum of Decree Law 2961/1941 (Brasil, 1941).

At the end of World War II, Brazil had direct assistance from the Massachusetts Institute of Technology (MIT) to plan and develop its own aeronautics industry. In 1950, the Aeronautics Institute of Technology (ITA) was created to train engineers and technicians to work in both the defense and commercial sectors (FAB, 2020).

The Brazilian Aeronautical Company (Empresa Brasileira de Aeronáutica Embraer) was established in 1969. Its impetus was governmental, aimed initially at the serial manufacture of the Bandeirante aircraft - already, at the time, designed for both civilian and military use. In 1981 Embraer signed an agreement with Italian companies Aeritalia (now Alenia) and Aermacchi to develop and manufacture the AMX, a subsonic fighter-bomber. The technologies developed for military purposes in this venture enabled civilian discoveries and innovations to be employed in commercial projects. The case of the AMX project is neither unique nor rare in the history of dual use in Brazilian aviation (Embraer, 2021).

Over the decades, Embraer has grown to become one of the largest aircraft manufacturing companies in the world. In 1994, it was privatized. In this transition, the federal government maintained a golden share, which meant that the company's strategic decisions, such as partnerships with foreign companies, needed the government's approval to take place (Embraer, 2021).

Embraer's 2019 revenue was between $\$ 5.3$ billion and $\$ 5.7$ billion (Embraer, 2019). The company emerges as the third largest manufacturer of commercial jets in the world, with more than 8,000 aircraft produced and about 18,000 employees. In 2020, an attempted joint venture between Embraer and Boeing in the United States failed (Octaviani, 2021). The company's recent military production includes the C-390 Millennium (formerly called the KC-390), a tactical transport, logistics, and in-flight refueling aircraft (Embraer, 2020). 


\subsection{Emgepron}

The Naval Projects Management Company (Empresa Gerencial de Projetos Navais, Emgepron) was created in 1982 and is a public company linked to the Navy. Emgepron develops and manages naval engineering initiatives. It is used by the Brazilian government to enable the commercialization of products and services with other nations, such as Ecuador and Namibia (Emgepron, 2021).

\subsection{Amazul}

Blue Amazon Defense Technologies (Amazônia Azul Tecnologias de Defesa, Amazul), created in 2012 by Law 12,706, is a public company focused on developing technologies for the Brazilian Nuclear Program (Amazul, 2021).

\section{7. $\mathrm{CBC}$}

The Brazilian Cartridge Company (Companhia Brasileira de Cartuchos, CBC) was founded in 1926. In 1939, due to the tensions of the Second World War, the company started to produce ammunition almost exclusively for the Brazilian Armed Forces. The company was nationalized in 1979. Through Imbel, the Army came to own 30\% of its shares, the other $70 \%$ being owned by private enterprise. In the 1990s, CBC opened a subsidiary in the United States, called Magtech. In 2003, this subsidiary was also expanded to Germany, with the opening of Magtech Europe. This strategy allowed the expansion of CBC's civilian product exports. In 2015, CBC acquired 52.67\% of the company Taurus, becoming its majority shareholder (CBC, 2021).

\subsection{Taurus}

Taurus Armas (Taurus Armas) was founded in 1939, due to the heightened tensions that would trigger the Second World War. At the time, President Getúlio Vargas encouraged the metallurgical industry to produce weapons. This incentive led a group of businessmen to open a company, initially importing firearms from Germany. Taurus is currently the second largest exporter of firearms to the United States, second only to the Austrian Glock (Taurus, 2021).

\subsection{Condor}

Condor Non-Lethal Technologies (Condor Tecnologias Não-Letais) was founded in 1985 and produces tear gas, impact and morale-boosting grenades, as well as rubber bullets and incapacitating electroshock devices. In 2001, the company started exporting armaments, under the control of the Brazilian Army. Currently, about half of Condor's production is exported to countries in Africa and the Middle East (Condor, 2021). 


\subsection{Iveco}

Iveco, established in 1975 in Italy, started its activities in Brazil in 1997. The company manufactures heavy vehicles, such as trucks and buses, and also some types of light vehicles (Iveco, 2021a). In 2011, Iveco began developing combat vehicles. In cooperation with the Army, the company started producing the armored VBTP-MR Guarani, for transport and combat operations (Iveco, 2021b).

\section{The Navy's Nuclear Program}

Brazil is a signatory to the Treaty on the Non-Proliferation of Nuclear Weapons (NPT), i.e. the country does not wish to develop nuclear weapons and has submitted to the International Atomic Energy Agency (IAEA). The design of the nuclear submarine is therefore relative to its propulsion. This, in turn, presents advantages over other forms, such as diesel-electric. This is because, in addition to the speed, autonomy, and silence of the nuclear propulsion, electrically-driven technology needs frequent charging, while diesel-based technology, in addition to the limitation of recharging, needs emersion for the oxygen used to burn fuel. The diesel-electric technology combines the limitations of both propulsions.

The Navy's Nuclear Program (Programa Nuclear da Marinha) began to be developed in 1979 and, according to official projections, should extend through to the 2030s (CTMSP, 2021b). It is one of the few Brazilian defense programs that spans decades and different governments. In 2008, an agreement was signed with France. This agreement provides for Brazilian technical assistance and training for the conception, design, manufacture, operation, and maintenance of submarines and their structures (Marinha do Brasil, 2021a). One of the highlights of the agreement is the Shipyard and Naval Base Itaguai (Itaguaí Construções Navais, ICN), created as a partnership between the Navy itself, the company Odebrecht, and the French Naval Group (Marinha do Brasil, 2020). The first phase is for the construction of four submarines with diesel-electric propulsion. This is already underway, with the launch of the Riachuelo Class submarines (derived from the Scorpène Class). The second phase foresees the construction of a nuclear-powered submarine (Marinha do Brasil, 2021b).

According to the Brazilian Navy, the Nuclear Program comprises: "1. the development of the Fuel Cycle; 2. the development of nuclear-electric generation" (CTMSP, 2011, translated by the author). Thus, the objectives are: the construction of nuclear propulsion submarines and the development of dual power generation technologies.

Brazil has tried to purchase some of the technologies needed for the submarine abroad. However, although it has expressly refused to develop nuclear weapons and has the necessary resources to acquire the equipment it orders, the country is constantly hindered because access to nuclear technology is internationally restricted (Brustolin, 2014).

Another highlight of the Program is the Aramar Experimental Center (Centro Experimental Aramar), located in Iperó (São Paulo). There, uranium enrichment tests are carried out. Aramar is one of the units of the aforementioned Navy Technology Center in São Paulo (Centro Tecnológico da Marinha em São Paulo, CTMSP). The other CTMSP unit is in an USP building, demonstrating its integration with academia (CTMSP, 2021a). 
As for the use of nuclear technology to produce electricity, it is important to note that in 1975 Brazil signed an agreement with Germany for the construction of eight nuclear reactors. The German company KWU, from the Siemens group, was in charge of the undertaking (however, only two plants have been delivered so far: Angra 1 and Angra 2), (FGV, 2021k). In 2018, Eletrobras (a mixedeconomy company under the shareholding control of the Federal Government) signed an agreement with France's EDF for the completion of Angra 3, whose construction has been halted since 2015. Previously, Eletrobras had already signed agreements with China's CNNC and Russia's Rosatom (Eletronuclear, 2021).

\section{Aerospace Sector}

In 2006, the governments of Brazil and Ukraine joined forces to create the Alcântara Cyclone Space (ACS), a binational public company with capital from both countries to develop aerospace technology. The goal would be to commercially exploit the orbiting of satellites by launching them with the Ukrainian Cyclone-4 rocket from Alcantara (in Maranhão), and to promote technology transfer to Brazil. However, in 2015, the cooperation between the two countries was cancelled by the Brazilian government after Russia annexed the Crimea region, where the main technological structures of interest to the program are located (Câmara dos Deputados, 2018).

The advantage of the Alcântara Space Center (Centro Espacial de Alcântara, CEA) over its competitors is its location on the Equator, which enables fuel savings in launches. In addition, the low air traffic in the region stands out in comparison with other launch centers. However, about $90 \%$ of the satellites in activity rely on components from the United States, which made launches unviable due to the lack of an agreement. In 2019, the Technology Safeguards Agreement (TSA) between Brazil and the United States came into force. One of the objectives was the commercial use of the CEA for occasional launches or long-term contracts (Brasil, 2020a).

Finally, we must highlight the work of the National Institute for Space Research (Instituto Nacional de Pesquisas Espaciais, INPE), created in 1961 and currently linked to the Ministry of Science, Technology, and Innovation. Focused on space research and exploration, it also works with meteorology, among other areas. Furthermore, INPE produces research on nuclear fusion, having designed and built one of the three experimental fusion reactors existing in Brazil (INPE, 2021).

\section{National structure}

Although timid in the face of its potential, and with decision-making processes that can drag on for decades, it is still fair to say that Brazil has been moving to make better use of its own structure. For example, in the acquisition of the Gripen NG fighter jet from the Swedish company Saab, after almost two decades of negotiations, the government opted for a proposal that allows the country to have joint participation in the development of the project, including national companies - such as Embraer - and local labor. The forecast is said to generate around 14.5 thousand direct and indirect jobs in Brazil (Airway, 2015). 
In addition, having rights to intellectual property was a determining factor in the agreement that put the French (Dassault, with the Rafale fighter jet) and the Americans (Boeing, with the F-18 Super Hornet fighter jet) ahead (Scandinavianway, 2019).

\subsection{Association of industries}

Created in 1985, the Brazilian Defense and Security Materials Industries Association (Associação Brasileira das Indústrias de Materiais de Defesa e Segurança, Abimde) currently has around 200 member companies. Among these, certain traditional companies stand out, such as Embraer, CBC, and Condor (Brustolin, 2016). Besides this, there are other companies and industries that work with defense in Brazil and that are not members of Abimde, but that, for inherent economic reasons, have an interest in the defense industrial base (Abimde, 2021).

\subsection{Academic research}

Regarding academic production in the area of defense, the National Defense White Paper (Livro Branco de Defesa Nacional, LBDN) is emphatic: "The awareness that the country is not immune to the risks and threats inherent to the relations between states was reinforced, favoring the sense of unity of researchers who used to work in isolation." The text adds: "Thus, new disciplines were created in international relations and political science courses, and specific courses on defense were instituted" (Brasil, 2012a). The White Paper is an official publication of the Brazilian government, having been created by Complementary Law 136/2010 and launched in 2012 (Brasil, 2010). The edition currently in force was approved in 2018 and published in 2020 (Brasil, 2020a).

\subsection{Strategy}

On 17 December 2008, for the first time in Brazil's history, a National Defense Strategy (Estratégia Nacional de Defesa, END) was published. This document, updated in 2012 and 2016, with a new revision of 2020 in process (Brasil, 2020b) states that the "reorganization of the defense industrial base, to ensure that the armed forces meet the needs of such products based on technologies under national domain, preferably those of dual use (military and civilian)", (Brasil, 2020c).

Throughout the document, besides the reaffirmation of the need for technologies of national domain, a sovereignty issue emerges: "National independence achieved by autonomous technological capacity, including in the strategic space, cybernetic and nuclear sectors. It is not independent who does not have the mastery of sensitive technologies, both for defense and for development" (Brasil, 2020c).

The Strategy was published following the National Defense Policy. It was approved by Decree 5.484/2005 (Brasil, 2005), and updated in 2012, changing its name to National Defense Policy (Politica Nacional de Defesa, PND). Currently, as well as the White Paper and the National Defense Strategy, the 2020 update of the National Defense Policy is being discussed in National Congress. Under Complementary Law 136/2010, these documents are updated every four years (Brasil, 2010). 
Among other legislation and priority documents for Brazil's defense industry, the following stand out:

- The Defense Articulation and Equipment Plan (Plano de Articulação e Equipamento de Defesa, PAED), first published in 2012 and updated in 2016. This details the projects for recomposing the operational capacity of the Navy, Army, and Air Force, with a focus on technological autonomy and strengthening the national defense industry (MD, 2020).

- The Law for the Promotion of the Defense Industrial Base (12.598/2012), is a milestone in the promotion of the defense industrial base. The law establishes the criteria for the classification of a "Strategic Defense Company". By qualifying as such, companies can benefit from the Special Taxation Regime for the Defense Industry (Regime Especial de Tributação para a Indústria de Defesa, Retid), which exempts them from certain charges, reducing their production costs (Brasil, 2012b). Currently, there are 113 accredited Strategic Defense Companies, and 27 others accredited as Defense Companies (MD, 2021a).

- The Ministry of Defense Decree 899/2005, which approves the National Defense Industry Policy (Política Nacional da Indústria de Defesa), (MD, 2005).

- The Ministry of Defense Ordinance 63/2018, which establishes the Defense Technological, Industrial and Commercial Offset Policy (Política de Compensação Tecnológica, Industrial e Comercial de Defesa), (MD, 2018).

- Decree 9,570/2018, which updates the structure of the Ministry of Defense. The emphasis is on article 38, where the competence of the Secretariat of Defense Products (Secretaria de Produtos de Defesa, Seprod) is described. This is responsible for creating the foundations, formulating, updating, and monitoring the execution of the National Defense Industry Policy; the National Defense Technological, Industrial, and Commercial Compensation Policy; and the Defense Science, Technology, and Innovation Policy. Seprod has played a considerable role, especially because it also conducts programs and projects to commercially promote the national defense industry (Brasil, 2018).

- Decree 10,030/2019, which approves the Controlled Products Regulation (Brasil, 2019).

- The National Cyber Security Strategy (Estratégia Nacional de Segurança Cibernética, E-Ciber), approved by Decree 10,222/2020, (Brasil, 2020d).

- The Ministry of Defense Ordinance 3,063/2021, which updates the Science, Technology and Innovation Policy for Defense (Política de Ciência, Tecnologia e Inovação para a Defesa, PCTID). The new Policy provides incentives for joint initiatives between the government, the defense industrial base, research centers and universities (MD, 2021b).

Having presented these guidelines, it is worth noting that the role of the State as a war industry entrepreneur occurs worldwide. Historically, this entrepreneurship has generated multiple-use innovations (Brustolin, 2014). 


\subsection{Threats to democracy}

It is important to point out that the regulatory framework listed above makes the current context quite different from that of the late 1980s. As shown, at the end of the military regime in 1985, there was a dismantling of the defense industry. Then, defense industry policies underwent profound changes in the 1990s and 2000s. The 2010s, on the other hand, project greater attention to the sector in the 2020s.

This raises the question about what will happen if President Bolsonaro boycotts the 2022 elections and remains in power, as he has threatened (Barbara, 2021). The latter came to power in 2019, with the retired General Antônio Hamilton Mourão as Vice President, and the support of sectors of the Armed Forces (McCoy and Sá Pessoa, 2021). Bolsonaro has made several statements about not allowing presidential elections in 2022, or not accepting the results if he is not re-elected (Garcia, 2021; Struck, 2021; Horta \& Conde, 2021). This possibility will be discussed below.

\section{Conclusion}

This article has looked at the role of the military in Brazil's industrial policies. Military and civilian technologies are close and "will almost always have dual utility, military and civilian", as stated in the National Defense Strategy (Brasil, 2008, 2012). That said, it is important to point out some facts in perspective:

Although the government played a limited role in industrial stimulation in the 1920s, World War I increased the general consensus that industry was an important part of development, particularly in the area of warfare. No wonder that the country's First Military Industrial Cycle benefited from the Revolution of 1930 and the "Industrial Revolution," which lasted from 1930 to 1936. Previously, its entire military industrial infrastructure used foreign technologies.

As shown, the first government of Getúlio Vargas (from 1930 to 1945), invested in the creation of industrial infrastructure, with a special focus on manufacturing industries. Vargas had first come to power via a coup d'état, and his government extended through the Great Depression and World War II. Here, again, it is worth pointing out that World War II had considerable influence on Brazil's industrialization. This is because the industrial focus of the world in the early 1940s was war, and because of this, Brazil was no longer able to import the necessary parts and machinery to industrialize. Therefore, as demonstrated, the Brazilian Military Research and Development cycle came about as a consequence of the War. On the other hand, the military cooperation agreement with the United States, signed in 1952, dampened Brazilian military technological development.

The infrastructure created during the 1950s favored the industrial development of Brazil as a whole. It was at this time, especially during the second Vargas government (1951-1954), that institutions such as the National Bank for Economic and Social Development (BNDES, 1952), the Coordination for the Improvement of Higher Education Personnel (CAPES, 1951), and the National Council for Scientific and Technological Development (CNPQ, 1951) were created. As noted, this structure, developed by the State, helped President Juscelino Kubitschek (1956-1961) to launch a Target Plan that accelerated the process of internationalization of the Brazilian economy. 
The military government began in 1964, and lasted for almost 21 years, until 1985. During this period, the defense industry benefited greatly, so that by the end of the 1980 s, about $90 \%$ of the means that mobilized the Brazilian Army were manufactured on national territory. For some time, national technologies were prioritized, especially when, in 1977, the government of Ernesto Geisel denounced the agreement signed in 1952 between Brazil and the United States. Other sectors also benefited from the industrialization of this period, especially since the infrastructure created before the military regime continued to function.

The political and social transformations of the 1990s and 2000s substantially reduced Brazil's defense industrial base. The National Defense Strategy, published in 2008, gave a new perspective to this area, prioritizing the nuclear, cyber and aerospace sectors. This article has presented the main institutions and companies created or installed in Brazil during the 20th and early 21st centuries. The focus has been the defense industrial base, but, as pointed out, technologies have had multiple uses and many of the companies involved in this industry also concern the civilian sphere. Furthermore, Brazilian development institutions (such as CAPES, CNPQ, and BNDES) have served both civil and military spheres.

That said, the military's influence on Brazilian industrialization policies is evident. Such influence was not always legitimized, as in the 1964 coup d'état and the consecutive military government (1964-1985). Furthermore, such influence was not always driven by internal factors, since political-military events, such as World War I, and above all, World War II, directly affected the country's industrialization policies.

During the 20th century, Brazil went from not producing defense equipment to becoming one of the largest exporters in the world. This role underwent profound changes in the 1990s and 2000s. The decade of 2010, as observed - both by the country's official guidelines (section 9.3) and by the performance of its main defense industries (sections 6 to 9) - allow us to assume that the sector will receive more attention in the 2020s.

On the other hand, and as noted throughout the article, at the end of the military regime in 1985, there was a dismantling of the defense industry. As shown, there was significant disinvestment in the area of defense around the world during the 1990s. This occurred mainly due to the dissolution of the Soviet Union and the end of the Cold War. However, since defense is a strategic area, Brazil could have avoided the dismantling of its defense industry. With the support of certain public policies - which are common for the defense industry worldwide - many defense companies could have sustained themselves by producing multiple-use technologies. Nevertheless, the civilian governments that Brazil had right after the military dictatorship (in the late 1980s and 1990s) did not rescue the defense industry. A conjunction of political and economic factors caused successive delays in most military programs, with many of them being cancelled.

Bolsonaro has threatened to bar presidential elections or to reject the results of an election if he is not re-elected. Should this happen, democracy in Brazil will once again be disrupted. The eventual breakdown of the democratic regime could cause a loss of investment in Brazil. Furthermore, if a new dictatorial regime takes power, what happened in the 1990s could repeat itself if and when democracy is re-established. That is, deindustrialization and the subsequent 
dismantling of what remains of the defense industry, which would also affect the civilian industry, due to increasing multiple uses of the technology.

This article has shown advances in Brazilian institutions, policies, legislation, and society in recent decades. The context of the 2020s is very different from that of the mid-1960s, when the world was going through the Cold War and the military took power in Brazil. The context of the 2020s is also different from that of the mid-1980s, when democracy was restored in Brazil and the Cold War was coming to an end. However, Bolsonaro's threat of military coup, with the supposed support of some military personnel - or their omission - demonstrates that civil-military relations in Brazil still need to evolve towards the consolidation of democracy.

\section{References}

ABDI, Agência Brasileira de Desenvolvimento Industrial (2011). Diagnóstico da Base Industrial de Defesa. Campinas: ABDI, NEIT-IE-UNICAMP [On-line]. Available at: www.eco.unicamp.br/neit/images/stories/arquivos/Relatorios_NEIT/Base-Industrial-de-DefesaBrasileira-Marco-de-2011.pdf (Accessed: 2 January 2022).

Airway. (2015) Projeto do caça Gripen NG vai gerar 14.500 empregos no Brasil [Online]. Available at: www.airway.com.br/projeto-do-caca-gripen-ng-vai-gerar-14-500-empregos-no-brasil (Accessed: 22 August 2021).

Alves, R. N. (2004) 'Indústria de Defesa: Uma proposta para reflexão', in Pinto, J. R. de A.; Rocha, A. J. R. da; Silva, R. D. P. da. (ed.) Pensamento Brasileiro sobre Defesa e Segurança. As Forças Armadas e o desenvolvimento científico e tecnológico do País, (vol. 3). Brasília: Ministério da Defesa.

Amaral, M. H. S. do. (2013) O poder pelo mar: a indústria de construção naval militar no Brasil a partir da política desenvolvimentista de Juscelino Kubitschek (1956-1961). Masters dissertation, Fundação Getúlio Vargas.

Amarante, J. A. do. (2004) 'Indústria Brasileira de Defesa: Uma questão de soberania e de autodeterminação' in Pinto, J. R. de A.; Rocha, A. J. R. da; Silva, R. D. P. da. (ed.) Pensamento Brasileiro sobre Defesa e Segurança. As Forças Armadas e o desenvolvimento científico e tecnológico do País, (vol. 3). Brasília: Ministério da Defesa.

Amazônia Azul Tecnologias de Defesa (Amazul). (2021) Competências [Online]. Available at: www.amazul.mar.mil.br/acesso-a--informacao-competencias-inicial (Accessed: 22 August 2021).

Associação Brasileira das Indústrias de Materiais de Defesa e Segurança (Abimde). (2021) Abimde comemora 36 anos com conquistas inovadoras para a Base Industrial de Defesa e Segurança (BIDS) [Online]. Available at: https://abimde.org.br/pt-br/noticias/abimde-comemora-36-anos-comconquistas-inovadoras-para-a-base-industrial-de-defesa-e-seguranca-bids (Accessed: 22 August 2021).

Ambrósio, M. (2016). O estabelecimento das bases para um complexo militar-industrial brasileiro durante os governos militares, A Defesa Nacional, 103 (830). [Online]. Available at: www.ebrevistas.eb.mil.br/ADN/article/view/3065/2462 (Accessed: 2 January 2022). 
Avibras. (2021) Quem somos [Online]. Available at: www.avibras.com.br/site/institucional/quemsomos.html (Accessed: 22 August 2021).

Banco Nacional de Desenvolvimento Econômico (BNDES). (2021) Nossa história, Memória BNDES [Online]. Available at: www.bndes.gov.br/wps/portal/site/home/quem-somos/nossa-historia (Accessed: 20 August 2021).

Barbara, V. (2021) Bolsonaro Is Getting Desperate, and It's Clear What He Wants, The New York Times, 15 September 2021 [Online]. Available at: www.nytimes.com/2021/09/15/opinion/bolsonarobrazil-independence-day.html (Accessed: 2 January 2022).

Brasil. (1941) Decreto-Lei № 2.961, de 20 de janeiro de 1941.

Brasil. (1988) Constituição da República Federativa do Brasil. Art. 84, XIII.

Brasil. (2005) Decreto № 5.484, de 30 de junho de 2005.

Brasil. (2008, 2012) Estratégia Nacional de Defesa [Online]. Available at: www.gov.br/defesa/ptbr/arquivos/2012/mes07/end.pdf (Accessed: 20 August 2021).

Brasil. (2008) Estratégia Nacional de Defesa [Online]. Available at: www.planalto.gov.br/ccivil_03/_ato2007-2010/2008/decreto/d6703.htm (Accessed: 20 August 2021).

Brasil. (2010) Lei Complementar № 136, de 25 de agosto de 2010.

Brasil. (2012a) Livro Branco de Defesa Nacional [Online]. Available at: www.gov.br/defesa/ptbr/arquivos/2012/mes07/lbdn.pdf (Accessed: 22 August 2021).

Brasil. (2012b) Lei № 12.598, de 21 de março de 2012.

Brasil. (2018) Decreto № 9.570, de 20 de novembro de 2018.

Brasil. (2019) Decreto № 10.030, de 30 de setembro de 2019.

Brasil. (2020a) Livro Branco de Defesa Nacional [Online]. Available at: www.gov.br/defesa/ptbr/assuntos/copy_of_estado-e-defesa/livro_branco_congresso_nacional.pdf (Accessed: 22 August 2021).

Brasil. (2020b) Política Nacional de Defesa \& Estratégia Nacional de Defesa [Online]. Available at: www.gov.br/defesa/pt-br/assuntos/copy_of_estado-e-defesa/pnd_end_congresso_.pdf (Accessed: 22 August 2021).

Brasil. (2020c) Estratégia Nacional de Defesa [Online]. Available at: www.gov.br/defesa/ptbr/assuntos/copy_of_estado-e-defesa/pnd_end_congressonacional_22_07_2020.pdf (Accessed: 22 August 2021).

Brasil. (2020d) Decreto № 10.220, de 5 de fevereiro de 2020.

Brayner, F. de L. (1968) A verdade sobre a FEB: Memórias de um chefe de Estado-Maior na Campanha da Itália, 1943-45. Rio de Janeiro: Ed. Civilização Brasileira.

Brustolin, V. (2014) Inovação e Desenvolvimento via Defesa Nacional nos EUA e no Brasil. Doctoral thesis,

B RASILIANA: Journal for Brazilian Studies. Vol. 10, No. 2, 2021. ISSN 2245-4373. 
Universidade Federal do Rio de Janeiro \& Harvard University. Available at: https://scholar.harvard.edu/brustolin/phd-thesis (Accessed: 21 August 2021).

Brustolin, V. (2016) 'Equipamentos de Uso Individual', in Mapeamento da Base Industrial de Defesa. Brasília: IPEA, ABDI, Ministério da Defesa. Available at: www.ipea.gov.br/portal/images/stories/PDFs/livros/livros/160706_livro_mapeamento_defesa.p df (Accessed: 22 August 2021).

Brustolin, V. \& Oliveira, D. de \& Peron, A. E. dos R. (2020) 'Exploring the relationship between crypto $\mathrm{AG}$ and the CIA in the use of rigged encryption machines for espionage in Brazil', Cambridge Review of International Affairs, DOI: https://doi.org/10.1080/09557571.2020.1842328.

Câmara dos Deputados. (2018) MP extingue empresa espacial criada com Ucrânia para explorar base de Alcântara [Online]. Available at: www.camara.leg.br/noticias/548506-mp-extingue-empresaespacial-criada-com-ucrania-para-explorar-base-de-alcantara (Accessed: 22 August 2021).

Cardoso, A. M. (2004) 'O papel da ciência e tecnologia na Defesa e Soberania Nacional', in Pinto, J. R. de A.; Rocha, A. J. R. da; Silva, R. D. P. da. (ed.) Pensamento Brasileiro sobre Defesa e Segurança. As Forças Armadas e o desenvolvimento científico e tecnológico do País, (vol. 3). Brasília: Ministério da Defesa.

Centro Tecnológico da Marinha em São Paulo (CTMSP). (2011) ‘Painel 4: Índice de Nacionalização dos Produtos de Defesa', in XI Encontro Nacional de Estudos Estratégicos. Rio de Janeiro: Escola Naval, 16-18 November.

Centro Tecnológico da Marinha em São Paulo (CTMSP). (2021a) Quem somos [Online]. Available at: www.marinha.mil.br/ctmsp/quem-somos (Accessed: 22 August 2021).

Centro Tecnológico da Marinha em São Paulo (CTMSP). (2021b) Programa Nuclear da Marinha [Online]. Available at: www.marinha.mil.br/ctmsp/programa-nuclear-da-marinha (Accessed: 22 August 2021).

Clausewitz, C. von. (1976) [1832] On War. Eds. Michael Howard and Peter Paret. Princeton: Princeton University Press.

Clausewitz, C. von. (1980) [1832] Vom Kriege. Ed. Werner Hahlweg (Hinterlassenes Werk des Generals Carl von Clausewitz. Vollständige Ausgabe im Urtext). Troisdorf: Dümmler, 19th ed.

Companhia Brasileira de Cartuchos (CBC). (2021) Sobre nós [Online]. Available at: www.cbc.com.br/sobre-nos/historia (Accessed: 22 August 2021).

Condor. (2021) Inovação para acompanhar um mundo que nunca para de mudar [Online]. Available at: www.condornaoletal.com.br/a-empresa (Accessed: 22 August 2021).

Coordenação de Aperfeiçoamento de Pessoal de Nível Superior (CAPES). (2021) Séries CAPES Campanha Nacional de Aperfeiçoamento de Nível Superior' [Online]. Available at: http://arquivohistorico.inep.gov.br/index.php/capes (Accessed: 20 August 2021).

Couto, R. C. (1999) Memória viva do regime militar - Brasil 1964-1985. Rio de Janeiro: Ed. Record, 1999.

Dórea, L. H. C. (2018) A evolução histórica do Ministério da Defesa e as ações desenvolvidas para a 
conscientização da sociedade brasileira sobre os assuntos de defesa. Masters dissertation. Escola de Comando e Estado-Maior do Exército.

Educa Brasil. (2021) Cursos técnicos registram crescimento e reforçam credibilidade [Online]. Available at: www.educamaisbrasil.com.br/educacao/carreira/cursos-tecnicos-registram-crescimento-ereforcam-credibilidade (Accessed: 22 August 2021).

Eletrobras (Eletronuclear). (2021) Angra 3 [Online]. Available at: www.eletronuclear.gov.br/NossasAtividades/Paginas/Angra-3.aspx (Accessed: 22 August 2021).

Embraer. (2019) Embraer divulga os resultados do $3^{\underline{o}}$ trimestre de 2019 [Online]. Available at: https://embraer.com/br/pt/noticias?slug=1206662-embraer-divulga-os-resultados-do-3-trimestrede-2019 (Accessed: 22 August 2021).

Embraer. (2020) Embraer entrega quarta aeronave C-390 Millennium à Força Aérea Brasileira [Online]. Available at: https://embraer.com/br/pt/noticias?slug=1206820-embraer-entrega-quartaaeronave-c-390-millennium-a-forca-aerea-brasileira (Accessed: 22 August 2021).

Embraer. (2021) História da Embraer [Online]. Available at: https://historicalcenter.embraer.com/br/pt/historia (Accessed: 22 August 2021).

Empresa Gerencial de Projetos Navais (Emgepron). (2021) Quem somos [Online]. Available at: www.marinha.mil.br/emgepron/pt-br/quem-somos (Accessed: 22 August 2021).

Escola de Comando e Estado-Maior do Exército (ECEME). (2021) Histórico [Online]. Available at: www.eceme.eb.mil.br/pt/historico-m-pt (Accessed: 21 August 2021).

Escola de Guerra Naval (EGN). (2018) Escola de Guerra Naval terá Curso de Doutorado em 2019 [Online]. Available at: www.marinha.mil.br/noticias/escola-de-guerra-naval-tera-curso-de-doutorado-em2019 (Accessed: 22 August 2021).

Escola de Guerra Naval (EGN). (2021a) Histórico [Online]. Available at: www.marinha.mil.br/egn/historico (Accessed: 22 August 2021).

Escola de Guerra Naval (EGN). (2021b) Programa de Pós-Graduação em Estudos Marítmos [Online]. Available at: www.marinha.mil.br/ppgem (Accessed: 22 August 2021).

Escola Naval (EN). (2021) A História da Escola Naval [Online]. Available at: www.marinha.mil.br/en/node/7 (Accessed: 22 August 2021).

Escola Superior de Guerra (ESG). (2021) A ESG [Online]. Available at: www.gov.br/defesa/ptbr/assuntos/esg/a-esg (Accessed: 22 August 2021).

Ferreira Lima, H. (1978) História Político-Econômica e Industrial do Brasil, (2 ed). São Paulo: Brasiliana.

Ferreira, M. J. B. \& Sarti, F. (2011) Diagnóstico: Base Industrial de Defesa Brasileira. Brasília: Agência Brasileira de Desenvolvimento Industrial (ABDI).

Força Aérea Brasileira (FAB). (2020) Especial: 70 anos da criação do ITA (1 ${ }^{a}$ década) [Online]. Available at: www.fab.mil.br/noticias/mostra/35763/INSTITUCIONAL\%20\%20Especial:\%2070\%20anos\%20da\%20cria\%C3\%A7\%C3\%A3o\%20do\%20ITA\%20(1\%C2\%AA\% 
20d\%C3\%A9cada) (Accessed: 22 August 2021).

Força Aérea Brasileira (FAB). (2021) História [Online]. Available at: www.fab.mil.br/80Anos (Accessed: 21 August 2021).

Fundação Getúlio Vargas (FGV). (2021a) Conselho Nacional do Petróleo, Centro de Pesquisa e Documentação de História Contemporânea do Brasil (CPDOC) [Online]. Available at: https://cpdoc.fgv.br/producao/dossies/AEraVargas1/anos37-

45/EstadoEconomia/ConselhoPetroleo (Accessed: 20 August 2021).

Fundação Getúlio Vargas (FGV). (2021b) CSN: uma decisão política, Centro de Pesquisa e Documentação de História Contemporânea do Brasil (CPDOC) [Online]. Available at: https://cpdoc.fgv.br/producao/dossies/FatosImagens/CSN (Accessed: 20 August 2021).

Fundação Getúlio Vargas (FGV). (2021c) Companhia Vale do Rio Doce, Centro de Pesquisa e Documentação de História Contemporânea do Brasil (CPDOC). [Online]. Available at: www.fgv.br/cpdoc/acervo/dicionarios/verbete-tematico/companhia-vale-do-rio-doce-cvrd (Accessed: 20 August 2021).

Fundação Getúlio Vargas (FGV). (2021d) Companhia Hidro Elétrica do São Francisco, Centro de Pesquisa e Documentação de História Contemporânea do Brasil (CPDOC) [Online]. Available at: www.fgv.br/cpdoc/acervo/dicionarios/verbete-tematico/companhia-hidro-eletrica-do-saofrancisco-chesf (Accessed: 20 August 2021).

Fundação Getúlio Vargas (FGV). (2021e) Acordo Militar Brasil-Estados Unidos (1952), Centro de Pesquisa e Documentação de História Contemporânea do Brasil (CPDOC) [Online]. Available at: www.fgv.br/cpdoc/acervo/dicionarios/verbete-tematico/acordo-militar-brasil-estados-unidos1952 (Accessed: 20 August 2021).

Fundação Getúlio Vargas (FGV). (2021f) Conselho Nacional de Desenvolvimento Científico e Tecnológico, $C N P Q$, Centro de Pesquisa e Documentação de História Contemporânea do Brasil (CPDOC) [Online]. Available at: www.fgv.br/cpdoc/acervo/dicionarios/verbete-tematico/conselhonacional-de-desenvolvimento-cientifico-e-tecnologico-cnpq (Accessed: 20 August 2021).

Fundação Getúlio Vargas (FGV). (2021g) Anos de Incerteza (1930 - 1937): Criação da Universidade de São Paulo, Centro de Pesquisa e Documentação de História Contemporânea do Brasil (CPDOC) [Online]. Available at: https://cpdoc.fgv.br/producao/dossies/AEraVargas1/anos3037/RevConstitucionalista32/USP (Accessed: 20 August 2021).

Fundação Getúlio Vargas (FGV). (2021h) O Brasil de JK - 50 anos em 5: o Plano de Metas, Centro de Pesquisa e Documentação de História Contemporânea do Brasil (CPDOC) [Online]. Available at: https://cpdoc.fgv.br/producao/dossies/JK/artigos/Economia/PlanodeMetas (Accessed: 20 August 2021).

Fundação Getúlio Vargas (FGV). (2021i) Acordo Militar Brasil-Estados Unidos (1952), Centro de Pesquisa e Documentação de História Contemporânea do Brasil (CPDOC) [Online]. Available at: http://www.fgv.br/cpdoc/acervo/dicionarios/verbete-tematico/acordo-militar-brasil-estadosunidos-1952 (Accessed: 20 August 2021). 
Fundação Getúlio Vargas (FGV). (2021j) Força Aérea Brasileira (FAB), Centro de Pesquisa e Documentação de História Contemporânea do Brasil (CPDOC) [Online]. Available at: http://fgv.br/cpdoc/acervo/dicionarios/verbete-tematico/forca-aerea-brasileira-fab (Accessed: 22 August 2021).

Fundação Getúlio Vargas (FGV). (2021k) Acordo Nuclear Brasil-Alemanha (1975) [Online]. Available at: https://cpdoc.fgv.br/producao/dossies/FatosImagens/AcordoNuclear (Accessed: 22 August 2021).

Garcia, R. T. (2021) Bolsonaro's war on Brazilian democracy is not over, Aljazeera, 22 September 2021 [Online]. Available at: www.aljazeera.com/opinions/2021/9/22/bolsonaros-war-on-braziliandemocracy-is-not-over (Accessed: 2 January 2022).

Godeiro, N. (2010) A indústria de defesa no Brasil e a Imbel. São Paulo: Instituto Latino Americano de Estudos Socioeconômicos.

Helibras. História [Online]. Available at: www.helibras.com.br/website/po/ref/Hist\%C3\%B3ria_90.html (Accessed: 22 August 2021).

Horta, F. \& Conde, G. (2021) O golpe de mestre do STF no golpe de Estado de Bolsonaro, Rede Brasil Atual, 7 September 2021 [Online]. Available at: www.redebrasilatual.com.br/blogs/blog-narede/2021/09/7-setembro-golpe-mestre-stf-golpe-estado-bolsonaro (Accessed: 2 January 2022).

Indústria de Material Bélico do Brasil (Imbel). (2021a) História [Online]. Available at: www.imbel.gov.br/institucional/quem-somos/principios-fundamentais (Accessed: 22 August 2021).

Indústria de Material Bélico do Brasil (Imbel). (2021b) Produtos Imbel [Online]. Available at: www.imbel.gov.br/index.php/\#produtos (Accessed: 22 August 2021).

Instituto Militar de Engenharia (IME). (2021) História [Online]. Available at: www.ime.eb.mil.br/pt/historia.html (Accessed: 20 August 2021).

Instituto Nacional de Pesquisas Espaciais (INPE). (2021) Sobre o INPE [Online]. Available at: www.inpe.br/faq/index.php?pai=1 (Accessed: 22 August 2021).

Instituto Tecnológico de Aeronáutica (ITA). (2021) A concepção [Online]. Available at: Www.ita.br/aconcepcao (Accessed: 20 August 2021).

Iveco. (2021a) A Iveco tem vocação internacional desde o seu nascimento [Online]. Available at: www.iveco.com/portugal/institucional/pages/empresa_historia.aspx (Accessed: 22 August 2021).

Iveco. (2021b) A força dos produtos Iveco em defesa do território nacional [Online]. Available at: www.iveco.com/brasil/institucional/pages/veiculos-de-defesa.aspx (Accessed: 22 August 2021).

Laux, P. (2013) Helibras 35 anos: a saga da única fabricante de helicópteros do Brasil [Online]. Available at: www.convergenciacom.net/pdf/livroHelibras35anos20-11.pdf (Accessed: 22 August 2021).

Lucena, L. C. de (2005). Um Breve Histórico do IME - Instituto Militar de Engenharia (Real Academia de Artilharia, Fortificação e Desenho, 1792) [Online]. Available at: www.ime.eb.mil.br/arquivos/Noticia/historicoIME.pdf (Accessed: 21 August 2021). 
Marinha do Brasil. (2020) Itaguaí Construções Navais realiza o embarque da Plataforma de Ventilação no Submarino "Tonelero" [Online]. Available at: www.marinha.mil.br/dgdntm/node/217 (Accessed: 22 August 2021).

Marinha do Brasil. (2021a) O PROSUB [Online]. Available at: www.marinha.mil.br/prosub/institucional (Accessed: 22 August 2021).

Marinha do Brasil. (2021b) PROSUB: Histórico [Online]. Available at: www.marinha.mil.br/programas-estrategicos/prosub (Accessed: 22 August 2021).

Mattei, L. \& Santos Júnior, J. A. dos. (2009) ‘Industrialização e Substituição de Importações no Brasil e na Argentina: Uma Análise Histórica Comparada', Revista de Economia, v. 35, n. 1 (year 33), p. 93-115, jan./april. Editora UFPR. [Online]. Available at: https://core.ac.uk/download/pdf/328059979.pdf (Accessed: 20 August 2021).

McCoy, T. \& Sá Pessoa, G. (2021) ‘Bolsonaro once said he’d stage a military takeover. Now Brazilians fear he could be laying the foundation for one'. The Washington Post, 23 July 2021 [Online]. Available at: www.washingtonpost.com/world/2021/07/23/brazil-bolsonaro (Accessed: 22 August 2021).

Ministério da Defesa (MD). (2005) Portaria Normativa No 899/MD, de 19 de julho de 2005.

Ministério da Defesa (MD). (2018) Portaria Normativa N63/GM-MD, de 22 de outubro de 2018.

Ministério da Defesa (MD). (2020) Plano de Articulação e Equipamento de Defesa (PAED) [Online]. Available at: www.gov.br/defesa/pt-br/assuntos/industria-de-defesa/paed/plano-de-articulacaoe-equipamento-de-defesa-paed (Accessed: 22 August 2021).

Ministério da Defesa (MD). (2021a) Relação Geral de Empresas Credenciadas como ED \& EED [Online]. Available at: www.gov.br/defesa/ptbr/arquivos/industria_de_defesa/legislacao/LISTAPEDPRODEEEDEDAtualizadaSiscaped22072 021.pdf (Access: 21 August 2021).

Ministério da Defesa (MD). (2021b) Portaria Normativa N³,063/GM-MD, de 22 de julho de 2021.

Octaviani, A. (2021) A Embraer e o ponto cego do direito concorrencial brasileiro [Online]. Available at: www.conjur.com.br/2021-fev-19/defesa-concorrencia-embraer-ponto-cego-direitoconcorrencial-brasileiro (Accessed: 22 August 2021).

Oliveira, A. J. B. de. (2021) Uma breve história da UFRJ [Online]. Available at: https://ufrj.br/acesso-ainformacao/institucional/historia (Accessed: 22 August 2021).

Pinheiro, A. C. (1996). The Brazilian economy in the nineties: retrospect and policy changes. Rio de Janeiro: BNDES, Departamento Econômico.

Plataforma Sucupira. (2021) Cursos Avaliados e Reconhecidos [Online]. Available at: https://sucupira.capes.gov.br/sucupira/public/consultas/coleta/programa/quantitativos/quantita tivoRegiao.xhtml (Accessed: 22 August 2021). 
Scandinavianway. (2019) Entenda por que o caça sueco Gripen é importante para o Brasil [Online]. Available at: https://scandinavianway.com.br/entenda-por-que-o-caca-sueco-gripen-eimportante-para-o-brasil (Accessed: 22 August 2021).

Silva, D. L. da \& Marksteiner, A. (2021) Trends in World Military Expenditure, 2020, Stockholm International Peace Research Institute [Online]. Available at: https://sipri.org/sites/default/files/2021-04/fs_2104_milex_0.pdf (Accessed: 21 August 2021).

Skidmore, T. E. (ed.) (1999) Brazil: Five Centuries of Change. New York: Oxford University Press.

Struck, J. 2021. Em protestos, Bolsonaro faz ameaça golpista ao STF, DW, 7 September, 2021 [Online]. Available at: www.dw.com/pt-br/em-protestos-bolsonaro-faz-amea\%C3\%A7a-golpista-ao-stf/a59114324 (Accessed: 2 January 2022).

Taurus. (2021) Sobre nós [Online]. Available at: https://taurusarmas.com.br/pt/institucional/sobre-nos (Accessed: 22 August 2021).

Universidade de São Paulo (USP), Faculdade de Direito. (2021b) A Faculdade: História [Online]. Available at: www.direito.usp.br (Accessed: 22 August 2021).

Universidade de São Paulo (USP). (2021a) A Universidade de São Paulo [Online]. Available at: www5.usp.br/institucional/a-usp (Accessed: 22 August 2021).

Universidade Federal de Pernambuco (UFPE), Centro de Ciências Jurídicas (CCJ). (2021) História Available at: www.ufpe.br/ccj (Accessed: 22 August 2021).

Universidade Federal do Rio de Janeiro (UFRJ). (2021a) A Universidade e os anos 1920 [Online]. Available at: http://memoria.sibi.ufrj.br/index.php/ufrj-decadas/anos-1920 (Accessed: 20 August 2021).

Universidade Federal do Rio de Janeiro (UFRJ). (2021b) Conheça a história da Escola Politécnica [Online]. Available at: https://poli.ufrj.br/a-politecnica/historia (Accessed: 22 August 2021).

Vinhosa, F. L. T. (1990) O Brasil e a Primeira Guerra Mundial. A diplomacia brasileira e as grandes potências. Instituto Histórico e Geográfico Brasileiro.

\section{Acknowledgments}

The author is grateful to William Edward Deacon and Matheus Freitas Dias for their crucial assistance. 